\title{
PERUBAHAN KONDISI SOSIAL EKONOMI MASYARAKAT SEBAGAI DAMPAK ADANYA PENGEMBANGAN OBJEK WISATA PANTAI OLELE
}

\author{
Kasim Mahmud ${ }^{\mathrm{a}}$, Yayu Indriati Arifin ${ }^{\mathrm{b}}$, Rusiyah $^{\mathrm{c}}$ \\ Jurusan Ilmu dan Teknologi Kebumian, Fakultas Matematika dan Ilmu Pengetahuan Alam, Universitas Negeri \\ Gorontalo Jln. .Jenderal Sudirma, Kota Gorontalo 96128, Indonesia \\ INFO ARTIKEL \\ Status artikel: \\ Diterima: 05-02-2021 \\ Disetujui: 28-02-2021 \\ Tersedia online: 04-03-2021

\section{Kata kunci:} \\ Beach Tourist Attraction, Development \\ Sosio-Economic Condition \\ Penulis korespondensi: \\ Kasim Mahmud \\ Jurusan ilmu dan teknologi kebumian, \\ Kota gorontalo 96128, indonesia \\ Email: kasimmahmud@gmail.com \\ DOI: $10.34312 /$ jgej.v2i1.10138 \\ Copyright (c) 2021 The Authors \begin{abstract}
The research objective is to find out the Socioeconomic Of Community After The Development Of Olele Beach Tourist Attraction Olele Village Olele Villag Kabila Bone Sub-District Bone Bolango District. It applies a quantitative descriptive method while the data were collected through techniques of observasi, interview, and documentation. Research samples are determined by applying purposive sampling. Technique of processing data uses editing, sorting, tabulating, and interpreting. Meanwhile, technique of data analysis employes table of percentage and diagram. Findings of research show that the inpact of development of beach tourist attractionis positive on the change of livelihood or job, business opportunity, and community income. In addition, the developmentof Olele Beach Tourist Attraaction inpacts community positively as the open new businesses as employment opportunity around the spot such as food and drink stalls, other types of stalls, and bost whereas gazebo, snorkeling, and oksigen tank are othertypes new services that are for rent for the visitors or tourists. In total, 26 unit of new business have opened after the development, and they employ 34 people. Lastly, the change of socioeconomic after the devepolment of beach touist attraction in Olele Village is an increase of $26,4 \%$ in respondents' incomes who open a new business opportunity.
\end{abstract}

\begin{abstract}
ABSTRAK
Tujuan penelitian ini adalah untuk mengetahui Sosial Ekonomi Masyarakat Pasca Pengembangan Objek Wisata Pantai Olele Desa Olele Desa Olele Kabila Bone Kecamatan Bone Bolango. Metode yang digunakan adalah metode deskriptif kuantitatif sedangkan pengumpulan data dilakukan melalui teknik observasi, wawancara, dan dokumentasi. Sampel penelitian ditentukan dengan menggunakan purposive sampling. Teknik pengolahan data menggunakan editing, sorting, tabulating, dan interpreting. Sedangkan teknik analisis data menggunakan tabel persentase dan diagram. Hasil penelitian menunjukkan bahwa pengembangan objek wisata pantai berpengaruh positif terhadap perubahan mata pencaharian atau pekerjaan, peluang usaha, dan pendapatan masyarakat. Selain itu, perkembangan Wisata Pantai Olele berdampak positif bagi masyarakat dengan terbukanya usaha-usaha baru sebagai lapangan kerja di sekitar spot seperti warung makan dan minum, warung lain, dan bost sedangkan gazebo, snorkeling, dan tangki oksigen merupakan jenis jasa baru yang lain. disewakan untuk para pengunjung atau turis. Secara total, 26 unit usaha baru dibuka setelah pengembangan, dan mempekerjakan 34 orang. Terakhir, perubahan sosial ekonomi pasca perusakan objek wisata pantai di Desa Olele terjadi peningkatan pendapatan responden yang membuka peluang usaha baru sebesar $26,4 \%$.
\end{abstract}

\section{Pendahuluan}

Sektor pariwisata di Indonesia saat ini dinilai efektif peranannya dalam menambah devisa negara. Hal tersebut tidak terlepas dari perkembangan kebutuhan pariwisata, tidak hanya di Indonesia, namun di seluruh dunia. Pertumbuhan kebutuhan manusia akan pariwisata menyebabkan sektor ini dinilai mempunyai prospek yang besar dimasa yang akan datang (Andereck et al., 2005). Sektor pariwisata mampu menghidupkan ekonomi masyarakat di sekitarnya, yang mengandalkan interaksi masyarakat (Kobi \& Hendra, 2020), 
Pariwisata juga diposisikan sebagai sarana penting dalam rangka memperkenalkan budaya dan keindahan alam daerah terkait. Banyak negara di dunia menganggap pariwisata sebagai invisible export atas barang dan jasa pelayanan kepariwisataan yang dapat memperkuat neraca pemasukan.

Pariwisata merupakan sumber pendapatan yang dapat terus diperbaharui dan diremajakan, dengan sistem pengelolaan pengembangan pariwisata (Butler, 1999; Lu \& Nepal, 2009; Sya et al., 2021), oleh sebab itu pariwisata merupakan investasi yang penting pada sektor non migas bagi Indonesia. Pariwisata merupakan investasi ekonomi masa depan, akan secara otomatis mempermudah pertukaran barang dan jasa pelayanan di tempat wisata. Pariwisata akan meningkatkan stabilitas ekonomi nasional, namun tentu saja keberhasilan dalam pengembangan pariwisata akan mampu dirasakan apabila faktor-faktor pendukungnya telah dipersiapkan dengan baik. Kegiatan wisata dapat dikembangkan dengan konsep ekowisata bahari yang dikelompokkan menjadi wisata pantai dan wisata bahari. Wisata pantai termasuk dalam kegiatan wisata yang fokus terhadap sumberdaya pantai dan budaya masyarakat pantai seperti rekreasi, olahraga, menikmati pemandangan dan iklim (Wunani et al., 2013). Sedangkan wisata bahari merupakan kegiatan yang mengutamakan sumber daya bawah laut dan dinamika air laut. Kegiatan wisata pantai merupakan salah satu jenis wisata yang paling banyak diminati oleh pengunjung, hal ini sejalan dengan kegiatan wisata pantai yang berada di Provinsi Gorontalo. Provinsi Gorontalo merupakan salah satu provinsi yang memiliki potensi wisata pantai yang sangat baik untuk dikembangkan (Suly Eraku et al., 2020)

Potensi wisata di wilayah Bone Bolango ini cukup prospektif khususnya untuk wisata bahari, namun demikian dari banyaknya potensi wisata tersebut belum dimanfaatkan secara optimal baik oleh masyarakat, pemerintah maupun investor. Pengembangan wisata tidak hanya tergantung dari faktor sumber daya alam saja, tetapi perlu memperhitungkan faktor lain yang tidak kalah pentingnya, seperti penyediaan fasilitas, aksesibilitas, keamanan dan sifat masyarakat sekitarnya dalam menerima kedatangan pengunjungnya.

Wisata Pantai Olele berdasarkan SK Bupati Bone Bolango No. 165 tahun 2006 tanggal 06 November 2006 tentang perairan Desa Olele Kabupaten Bone Bolango sebagai Kawasan Konservasi Laut Daerah Desa Olele Kecamatan Kabila Bone, bertujuan sebagai salah satu tempat pariwisata untuk melakukan diving dan snorkeling. Faktor-faktor itu akan memberikan dampak positif untuk masyarakat dan pengembangan pariwisata (Pathare, 2020). Pariwisata yang membutuhkan partisipasi masyarakat (Maku \& Pariono, 2020). Objek wisata di Desa Olele ini mampu memberikan peningkatan pendapatan asli daerah (PAD) dan juga pendapatan masyarakat sekitar Pantai Wisata Olele. Sebagian besar masyarakat yang tinggal di sekitar Pantai Olele bermata pencaharian sebagai nelayan. Masyarakat yang memiliki mata pencaharian seperti pedagang, petani dan buruh itu sangat sedikit, sehingga ini dapat memberikan nilai tersendiri untuk memanfaatkan dan mengembangkan ekonomi masyarakat. Setelah adanya objek wisata ini dapat memberikan informasi terkait dengan kondisi sosial ekonomi masyarakat sebagai suatu pengembangan atau pembangunan pariwisata kedepannya. Kajian mengenai kondisi sosial ekonomi masyarakat setelah adanya pengembangan objek wisata ini sebagai salah satu sumber informasi bagi masyarakat dan pemerintah Desa Olele, Kecamatan Kabila Bone, Kabupaten Bone Bolango, sehingga mampu memberikan gambaran tentang kondisi sosial ekonomi dan pengembangan yang ada di Desa Olele.

Penelitian tentang wisata pantai Olele sebelumnya hanya pada pemberdayaan sumber daya manusia lokal melalui pelatihan bahasa inggris untuk pemandu wisata dalam rangka optimalisasi taman laut olele (Bay et al., 2017) belum pernah dilakukan sebelumnya, terutama dalam melihat dampak dari pengembangan potensi wisata pantai Olele. Berdasarkan penjelasan tersebut maka dari itu peneliti tertarik untuk melakukan penelitian tentang perubahan sosial ekonomi masyarakat sebagai dampak pengembangan wisata pantai Olele.

\section{Metode}

\subsection{Lokasi dan Waktu}

Penelitian ini dilakukan di Desa Olele, Kecamatan Kabila Bone, Kabupaten Bone Bolango. Waktu dalam penelitian ini dilaksanakan dalam kurun waktu \pm 6 bulan, yaitu di bulan November 2019 sampai dengan Februari 2020. 


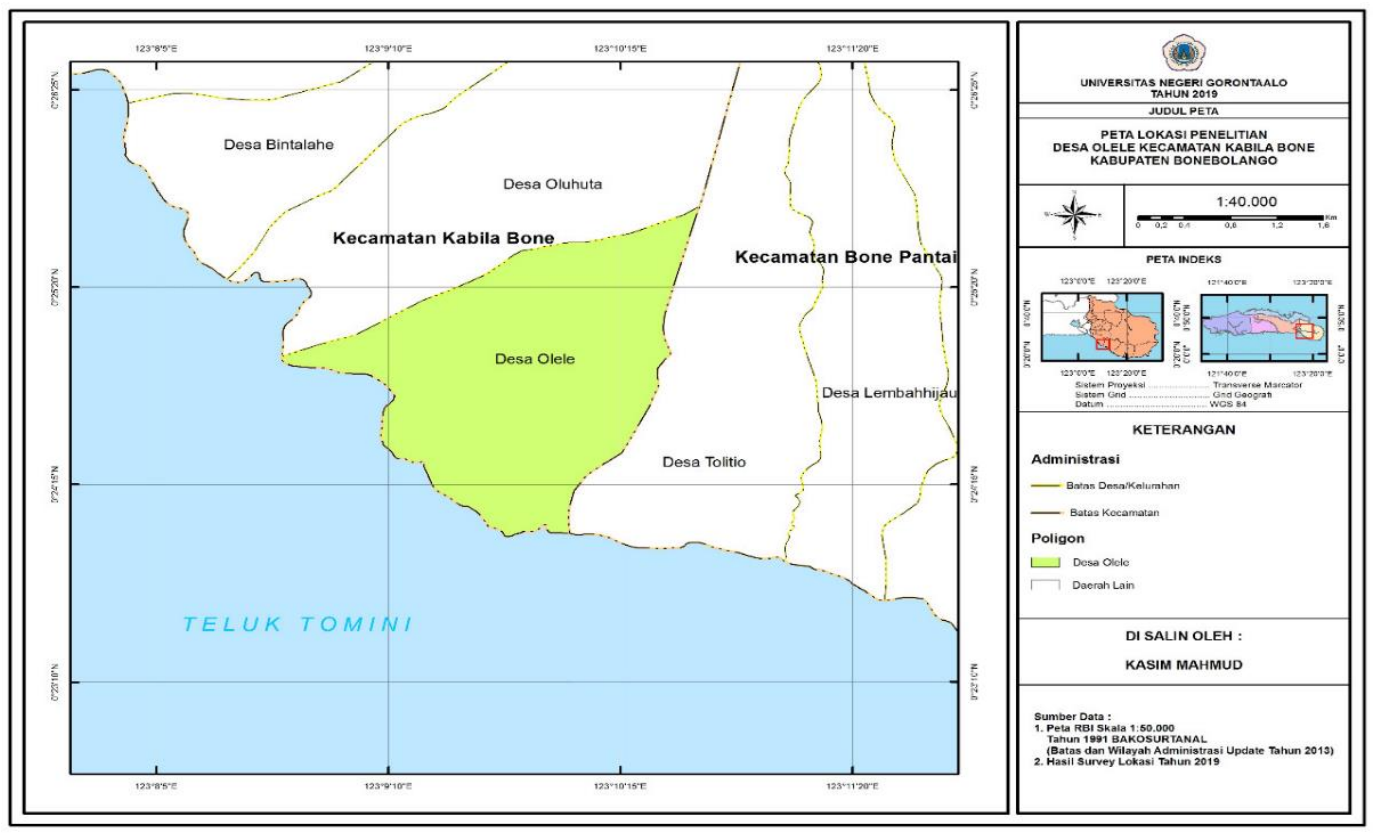

Gambar 1. Peta Lokasi Penelitian

\subsection{Variabel Penelitian}

Variabel penelitian adalah segala sesuatu yang berbentuk apa saja yang ditetapkan oleh peneliti untuk dipelajari sehingga diperoleh informasi tentang hal tersebut, kemudian ditarik kesimpulan Sugiyono (2013). Variabel dalam penelitian ini adalah kondisi sosial ekonomi masyarakat dilihat beberapa aspek yang dinilai, dan penelitian ini hanya difokuskan pada kondisi sosial ekonomi masyarakatnya seperti pendidikan, pekerjaan, pendapatan, dan peluang usaha.

\subsection{Populasi dan Sampel}

Populasi dalam penelitian ini adalah seluruh masyarakat yang tinggal di wisata Pantai Desa Olele, Kecamatan Kabila Bone yang berjumlah sebanyak 330 KK, Metode penarikan sampel dilakukan dengan purposive sampling, yaitu penentuan sampel dengan mempertimbangkan kriteria tertentu dari populasi menjadi sampel. Pemilihan sampel dalam penelitian ini adalah anggota keluarga atau masyarakat yang melakukan aktivitas kegiatan ekonomi seperti jenis pekerjaan, dan, jenis usaha yang ada di sekitar Wisata Pantai Olele dengan jumlah sampel yaitu sebanyak 76 KK.

\subsection{Jenis Dan Sumber Data}

Data yang digunakan dalam penelitian ini berdasarkan pengelompokannya terbagi atas dua jenis, yaitu: 1). Data Primer, Dalam penelitian ini data diperoleh dari jawaban responden yang ada di obyek wisata Pantai Olele dan di sekitarnya terhadap wawancara pengisian kuesioner yang disampaikan langsung oleh peneliti, jenis data primer yang dapat diperoleh dalam penelitian ini adalah berupa data tingkat pendidikan, data jenis pekerjaan, data peluang usaha dan, data pendapatan. 2). Data sekunder merupakan sumber data penelitian yang diperoleh peneliti secara tidak langsung melalui media perantara atau dicatat oleh pihak lain. Data tersebut dapat diperoleh dari kantor desa maupun sumber media lain yang berkaitan tentang luas wilayah serta data kependudukan Desa Olele.

\subsection{Teknik Pengumpulan Data}

Metode pengumpulan data yang digunakan dalam penelitian ini yaitu melalui 1). Kuesioner yaitu bertujuan untuk mengumpulkan data data dengan mengajukan pertanyaan yang sudah disediakan peneliti untuk dijawab oleh masyarakat maupun kepala keluarga yang ada di Objek Wisata 
Pantai Olele, Desa Olele. 2). Wawancara yaitu pengumpulan data dengan melakukan wawancara langsung dengan pihak-pihak yang berkompoten memberikan data informasi, dalam hal ini penelitian mewawancarai Lurah, pengelolah wisata, dan masyarakat. 3). Dokumentasi yaitu mengenai data-data yang telah didokumentasikan, dalam hal ini sumber informasinya berupa bahan-bahan atau yang sudah tercatat. Studi dokumentasi ini tidak secara langsung ditujukan kepada subjek penelitian.

\subsection{Teknik Analisis Data}

Analisis yang digunakan dalam penelitian ini adalah analisis deskriptif kuantitatif. Data dalam penelitian kuantitatif merupakan hasil pengukuran terhadap keberadaan suatu variabel. Variabel yang diukur merupakan gejala yang menjadi sasaran pengamatan penelitian. Analisis ini untuk mendeskripsikan, menggambarkan, menjabarkan, atau menguraikan data (Sugiyono, 2018). Mendeskripsikan keadaan responden sesudah pengembangan obyek wisata. Faktor yang dianalisis adalah aktivitas sosial, dan aktivitas ekonomi, dilihat tingkat pendidikan, tingkat pekerjaan, dan tingkat pendapatan. Sehingga dapat memberikan penjelasan tentang kondisi sosial ekonomi masyarakat setelah adanya pengembangan objek wisata Pantai Olele, kemudian hasil penelitian yang telah diolah selanjutnya dianalisis dan akan disajikan dalam bentuk tabel persentase dan diagram.

\section{Hasil dan Pembahasan}

\subsection{Hasil}

Berdasarkan penelitian yang telah dilakukan, peneliti menemukan beberapa karakteristik responden, karena tingkat sosial ekonomi masyarakat di wilayah desa objek wisata pantai Olele berbeda-beda, maka dalam penelitian ini peneliti menentukan beberapa kriteria yaitu jenis pekerjaan, tempat tinggal, peluang usaha, dan pendapatan.

Kondisi Sosial Ekonomi Sebelum Adanya Pengembangan Objek Wisata Pantai Tabel 1 Karakteristik Responden Berdasarkan Jenis Pekerjaan Sebelum Pengembangan Objek Wisata Pantai Olele

\begin{tabular}{ccc}
\hline Jenis Pekerjaan & Jumlah Responden & Persentase \\
\hline Petani & 9 & $11 \%$ \\
\hline Nelayan & 43 & $57 \%$ \\
\hline Wiraswasta & 6 & $7 \%$ \\
\hline Aparat Desa & 1 & $1 \%$ \\
\hline Buruh & 1 & $1 \%$ \\
\hline IRT & 17 & $23 \%$ \\
\hline Total & 76 & $100 \%$
\end{tabular}

Berdasarkan Tabel 1 Karakteristik responden berdasarkan angkatan kerja yang bekerja dalam berbagai bidang yaitu sebagai petani 9 orang atau persentase $11 \%$, nelayan sebanyak 51 orang dengan persentase $67 \%$, wiraswasta 6 orang persentase 7\%, IRT 17 orang dengan persentase 20\%, sedangkan aparat Desa dan buruh dengan persentase $1 \%$. Dalam hal ini menggambarkan bahwa masyarakat di Desa Olele memilki pekerjaan yang sangat monoton yaitu di bidang Nelayan sebanyak 43 orang. 
Tabel 2 karakteristik Responden Berdasarkan Pendapatan Sebelum Pengembangan Objek Wisata Pantai Olele

\begin{tabular}{lcc}
\hline \multicolumn{1}{c}{ Pendapatan } & Jumlah Responden & Persentase \\
\hline$<$ Rp. $500.000,00$ & 16 & $21 \%$ \\
\hline Rp. $500.000 .00-<$ Rp. $1000.000,00$ & 50 & $65 \%$ \\
\hline Rp. 1000.000.00-<Rp. 1.500.000,00 & 10 & $14 \%$ \\
\hline Rp. 1.500.000.00-<Rp. 2000.000,00 & 0 & $0 \%$ \\
\hline Total & 76 & $100 \%$ \\
\hline
\end{tabular}

Berdasarkan Tabel 2 Bahwa Pendapatan masyarakat sebelum pengembangan objek wisata di Desa Olele, berdasarkan data UMR 2020 golongan pendapatan masyarakat dibedakan menjadi beberapa bagian pendapatan, yaitu pendapatan sangat rendah <Rp. 500.000 .00 sebanyak $21 \%$, kemudian $65 \%$ masyarakat berpendapatan rendah Rp. 500.000.00-<Rp 1.000.000.00, sedangkan untuk masyarakat yang berpendapatan cukup tinggi yaitu Rp.1.000.000.00-<Rp. 1.500.000.00 sebanyak 14\%.

Kondisi Sosial Ekonomi Masyarakat Desa Olele Sesudah Adanya Pengembangan Objek Wisata Pantai Olele

\section{Tempat Tinggal}

Tempat tinggal dapat dikatakan sebagai salah satu tempat untuk melakukan kegiatan sosial ekonomi, dimana satu keluarga tinggal atau menempatinya. Apabila tempat yang ditinggali tersebut berbeda dalam hal ukuran dan kualitas. Tempat tinggal dengan ukuran besar, permanen dan milik pribadi dapat menunjukkan bahwa kondisi sosial ekonominya tinggi, semi permanen dan menyewa menunjukkan bahwa kondisi sosial ekonominya rendah, dapat dilihat pada tabel

Tabel 3 Perubahan Status Tempat Tinggal Sebelum dan Setelah Pengembangan Objek Wisata Pantai Olele.

\begin{tabular}{cccc}
\hline Jenis Tempat Tinggal & Sebelum pengembangan & Sesudah pengembangan & $\begin{array}{c}\text { Selisih } \\
\text { Persentase }\end{array}$ \\
\hline Rumah Sendiri & 62 & 62 & 0 \\
\hline Rumah Orang Tua & 14 & 14 & - \\
\hline Rumah Dinas & - & - & - \\
\hline Rumah Kontrak/Sewa & - & & 0 \\
\hline Total & 76 & - & 0 \\
\hline
\end{tabular}

Berdasarkan Tabel 3 Status kepemilikan rumah yang ada di Desa Olele, sebelum adanya pengembangan objek wisata Pantai Olele adalah milik sendiri ini tidak mempengaruhi terhadap aktivitas ekonomi responden karena sebagian masyarakat yang bekerja sebagai nelayan mampu memenuhi kebutuhan rumah tangga mereka sendiri.

\section{Pekerjaan}

Berdasarkan hasil penelitian yang telah dilakukan, pekerjaan merupakan sesuatu yang harus dikerjakan untuk mendapatkan upah atau imbalan lain, pekerjaan secara umum sebagai sebuah kegiatan aktif dalam menghasilkan sebuah karya yang bernilai imbalan dalam bentuk uang atau bentuk lainnya. Pekerjaan yang dimiliki berdampak terhadap pengembangan Objek Wisata Pantai Olele di Desa Olele, jenis pekerjaan di Desa Olele sangat membantu untuk pertumbuhan ekonomi masyarakat. Adanya perubahan pekerjaan pada 
masyarakat setelah pengembangan cukup memenuhi kebutuhan sehari-hari. Untuk mengetahui jenis pekerjaan masyarakat dapat dilihat pada tabel 4 Perubahan Mata Pencaharian atau Pekerjaan Responden Setelah Adanya Pengembangan Objek Wisata Pantai Olele.

Tabel 4 Perubahan Mata Pencaharian atau Pekerjaan Responden Setelah Adanya Pengembangan Objek Wisata Pantai Olele.

\begin{tabular}{cccc}
\hline & & Sesudah Pengembangan Objek & \\
No & Mata pencaharian penduduk & Persentase \\
\cline { 3 - 4 } & & Responden & \\
\hline 1 & Tidak bekerja pada sektor pariwisata & 24 & $31,58 \%$ \\
\hline 2 & $\begin{array}{c}\text { Bekerja pada sektor usaha pariwisata sebagai } \\
\text { pekerjaan sampingan }\end{array}$ & 10 & $13,16 \%$ \\
\hline 3 & $\begin{array}{c}\text { Bekerja pada sektor usaha pariwisata sebagai } \\
\text { pokok }\end{array}$ & 42 & $55,26 \%$ \\
\hline \multicolumn{2}{c}{ Total } & $100 \%$ \\
\hline
\end{tabular}

\section{Peluang Usaha}

Berdasarkan hasil penelitian yang telah dilakukan, peluang usaha yang ada di lokasi penelitian sangat dimanfaatkan dengan baik oleh masyarakat yang ada di sekitar objek wisata pantai, peluang usaha atau kesempatan kerja ini mampu memberikan pekerjaan baru bagi masyaraka untuk mengenbangankan usaha mereka. Peluang usaha atau kesempatan kerja dalam pengertiannya adalah suatu tujuan untuk mencapai keuntungan, dan kekayaan dalam membuka usaha dengan memanfaatkan sumber daya yang ada. Peluang usaha atau kesempatan kerja di Desa Olele sebelum dan setelah adanya pengembangan mengalami perubahan, untuk lebih jelasnya dapat dilihat pada Tabel 5 Jenis dan Peluang Usaha Objek Wisata Pantai Olele.

Tabel 5 Jenis dan Peluang Usaha Objek Wisata Pantai Olele

\begin{tabular}{clc}
\hline No & \multicolumn{1}{c}{ Jenis Usaha } & Tarif (Rp) \\
\hline 1 & Gazebo Ukuran Besar & Rp. 300.000 .00 \\
\hline 2 & Fasilitas Renang dan Perahu Wisata & Rp. 500.000 .00 \\
\hline 3 & Ruang Bilas & Rp. 0 \\
\hline 4 & Parkir & Rp. 0 \\
\hline 5 & Snorkling dan Tabung Renang & $\leq$ Rp. 800.000 .00 \\
\hline
\end{tabular}

Berdasarkan Tabel 5 jenis usaha dan tarif di objek wisata Pantai Olele dengan menggunakan analisis pendekatan Ecological Approach dengan analisis perilaku manusia terhadap lingkungannya menunjukan berbagai jenis usaha serta tarifnya yang ada di kawasan Objek Wisata Pantai Olele. Jenis usaha tersebut merupakan salah satu fasilitas yang ada dan sedang berkembang ini memberikan dampak terhadap peningkatan pendapatan masyarakat yang ada di Desa Olele.

Jenis usaha yang dikembangkan berupa gazebo, fasilitas renang dan perahu, ruang bilas, parkir, serta snorkeling dan tabung renang. Gazebo berfungsi sebagai tempat persinggahan atau tempat istirahat bagi pengunjung yang ingin bersantai, tarif gazebo yang disewakan oleh pengelolah untuk pengunjung adalah $\mathrm{Rp}$. 300.000.00 tanpa harus membatasi para wisatawan atau disewakan secara rombongan. 
Fasilitas renang yang disediakan dan disewakan adalah perahu wisata dengan kapasitas sekitar 10 sampai 15 dikenakan tarif Rp. 500.000.00, adapun fasilitas renang lainnya seperti snorkeling dan tabung renang serta perlengkapannya ini dikenakan dengan tarif Rp 800.000.00 dalam satu kali pemakaian. Adapun fasilitas lain seperti ruang bilas dan parkir untuk kendaraan roda dua maupun roda empat tidak dikenakan tarif harga. Masyarakat yang membuka usaha di sekitar Objek Wisata Pantai Olele itu memiliki pendapatan yang lebih besar dalam satu pekan, penghasilan yang didapatkan dalam satu bulan dapat mencapai >Rp. 2.000.000.00.

\subsection{Pembahasan}

Berdasarkan hasil penelitian yang telah dilakukan, jenis pekerjaan sangat mempengaruhi pada pendapatan masyarakat Desa Olele sebelum dan setelah pengembangan. Karena, dengan adanya pengembangan objek wisata mampu meningkatkan penghasilan anggota keluarga yang bekerja di sekitar objek wisata pengembangan ini sangat baik untuk memperbaiki kondisi sosial ekonomi masyarakat.

Tabel 10 Perubahan Jumlah Pendapatan Masyarakat Sebelum Dan Setelah Pengembangan Objek Wisata Pantai Olele.

\begin{tabular}{lcccc}
\hline No & Jumlah Pendapatan & $\begin{array}{c}\text { Sebelum } \\
\text { Pengembangan }\end{array}$ & $\begin{array}{c}\text { Sesudah } \\
\text { Pengembangan }\end{array}$ & $\begin{array}{c}\text { Selisih } \\
\text { Persentas } \\
\text { e }\end{array}$ \\
\hline 1 & Rp. $500.000,00$ & 16 & 16 & $0 \%$ \\
\hline 2 & Rp. 500.000,00-Rp.1000.000,00 & 50 & 50 & $0 \%$ \\
\hline 3 & Rp. 1.000.000,00-Rp. $1.500 .000,00$ & 10 & 0 & $13,2 \%$ \\
\hline 4 & Rp. 1.500.000,00-Rp. 2000.000,00 & 0 & 10 & $13,2 \%$ \\
\hline 5 & Total & & & $26,4 \%$ \\
\hline
\end{tabular}

Berdasarkan Tabel 10 Perubahan jumlah pendapatan masyarakat sebelum dan sesudah pengembangan objek wisata pantai dengan menggunakan pendekatan Ecological Approach yaitu analisis interaksi aktivitas manusia terhadap lingkungan dapat diketahui bahwa total jumlah perubahan jumlah pendapatan yang didapatkan dalam sebulan adalah Rp. 2.788.000.00 (UMR 2020), berdasarkan UMR 2020 golongan pendapatan tinggi jika >Rp.1.500.000.00-<Rp. 2.000.000.00, pendapatan >Rp. 1.000.000.00-<Rp. 1.500.000.00 dikategorikan cukup tinggi, sehingga pendapatan masyarakat di Desa Olele yang berada di atas $\geq$ Rp. 2.000.000.00 dapat digolongkan sangat tinggi, hal ini dipengaruhi oleh masyarakat yang pekerjaannya sebagai wiraswasta. Tetapi pendapatan responden sebagai nelayan juga sedikit mempengaruhi pendapatan yang diterima sehingga semakin terpenuhi dengan baik. Kesejahteraan dan kebutuhan responden dapat diasumsikan akan semakin baik dari sebelum adanya pengembangan Objek Wisata Pantai Olele.Untuk mengetahui gambarannya dapat dilihat pada Gambar 2 Grafik perubahan jumlah pendapatan sebelum dan setelah pengembangan.

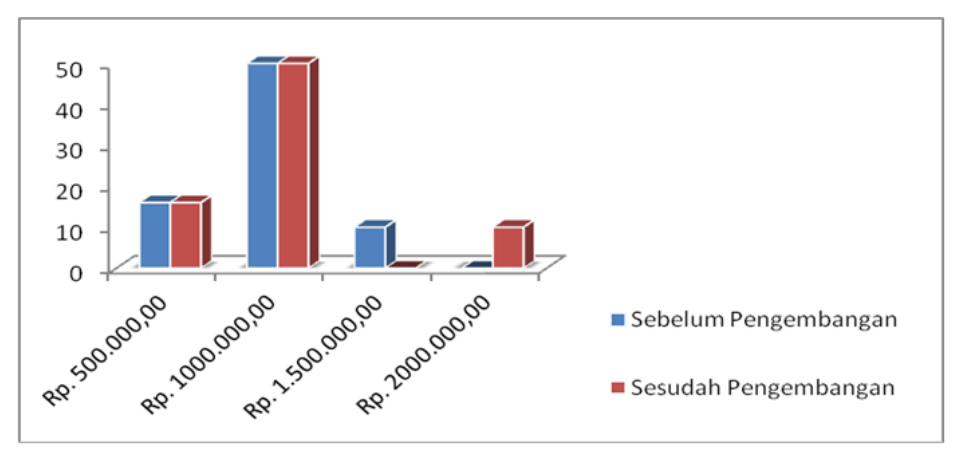

Gambar 2. Grafik Perubahan Jumlah Pendapatan Sebelum dan Setelah Pengembangan

Berdasarkan Gambar 2 menunjukan perbandingan aktivitas dan perubahan jumlah pendapatan sebelum dan sesudah pengembangan Objek Wisata Pantai Olele. Sebelum pengembangan objek wisata masyarakat masih memenuhi kebutuhan hidupnya sebagai petani, nelayan, wiraswasta, buruh serta ibu rumah tangga (IRT). Namun sesudah adanya pengembagan objek wisata aktivitas dan pendapatan masyarakat meningkat 
dengan memperoleh pekerjaan baru sebagai pekerjaan tambahan, responden sebagai wiraswasta membuka usaha seperti penyewaan Gazebo dan snorkeling serta tabung gas renang sedangkan masyarakat sebagai petani, nelayan, buruh, dan IRT pekerjaannya bertambah yaitu berdagang dengan membuka warung makan/minuman, kios-kios dan menyewakan saja, penyewaan saja yang ditawarkan adalah perahu wisata untuk melihat pemandangan dibawah laut. Perubahan pendapatan sesudah pengembangan yang paling meningkat adalah dengan jumlah Rp. 1.500.000.00-Rp. 2.000.000.00. Total jumlah peningkatan pendapatan ada 26,4\% selisih dari perubahan sebelum dan sesudah adanya dampak pengembangan objek wisata pantai.

\section{Kesimpulan}

Pengembangan objek wisata di Desa Olele memberikan dampak yang baik terhadap jenis usaha yang dibuka oleh masyarakat yaitu semakin banyak peluang usaha yang dibuka, jenis usaha yang dibuka pun sangat beragam dan paling nampak adalah jenis usaha seperti warung warung atau kios-kios. Masyarakat yang membuka peluang usaha warung warung atau kios-kios di kawasan objek wisata pantai, serta jenis usaha lain yang dibuka oleh masyarakat sebagai wiraswasta disewakan untuk para wisatawan seperti gazebo, snorkeling dan tabung renang. Sesudah pengembangan Objek Wisata Pantai Olele pendapatan responden rata-rata dalam perbulan di atas $\geq$ Rp. 2.000.000.00 namun pendapatan masyarakat tersebut masih berada dibawah UMR Provinsi Gorontalo yang rata-rata sekitar Rp. 2.788.000.00, meskipun tidak semua responden yang bekerja dan membuka usaha. Akan tetapi, responden yang bekerja sebagai nelayan dan buruh menawarkan pelayanan dalam bentuk jasa.

\section{Referensi}

Andereck, K. L., Valentine, K. M., Knopf, R. C., \& Vogt, C. A. (2005). Residents' perceptions of community tourism impacts. Annals of Tourism Research, 32(4), 1056-1076. https://doi.org/10.1016/j.annals.2005.03.001

Bay, I. W., Husain, N., \& Badu, H. (2017). pemberdayaan sdm lokal melalui pelatihan bahasa inggris untuk pemandu wisata dalam rangka optimalisasi taman laut olele. Ideas: Jurnal Pendidikan, Sosial, Dan Budaya, 3(3), 417.

Butler, R. W. (1999). Le tourisme durable: Un état de la question. Tourism Geographies, 1(1), 7-25. https://doi.org/10.1080/14616689908721291

Kobi, W., \& Hendra, H. (2020). Kajian geografi ekonomi: studi kasus kondisi sosial ekonomi masyarakat suku bajo di popayato, gorontalo. Jambura geo education journal, 1(1), 16-25. https://doi.org/10.34312/jgej.v1i1.4637

Lu, J., \& Nepal, S. K. (2009). Sustainable tourism research: An analysis of papers published in the Journal of Sustainable Tourism. Journal of Sustainable Tourism, 17(1), 5-16. https://doi.org/10.1080/09669580802582480

Maku, D., \& Pariono, A. (2020). Peran Kepala Desa Dalam Penyelesaian Konflik Di Obyek Wisata Pantai Botutonuo Kecamatan Kabila Bone Kabupaten Bone Bolango. Publik: Jurnal Manajemen Sumber Daya Manusia, Administrasi Dan Pelayanan Publik, 5(2), 78-86. https://doi.org/10.37606/publik.v5i2.27

Pathare, A. (2020). Geography and Tourism. In Geography of Tourism (pp. 1-15). Goodfellow Publishers. https://doi.org/10.23912/9781911396437-3642

Sugiyono. (2018). Metode Penelitian Kuantitatif, Kualitatif, dan R\&D. Alfabeta.

Suly Eraku, S., Karmin Baruadi, M., Permana, A. P., Hendra, H., \& Mohamad, N. (2020). Potensi Ekowisata Pantai Molotabu Kabupaten Bone Bolango Berdasarkan Analisis Spasial Ekologis (The Potential of Molotabu Beach Ecotourism, Bone Bolango Regency Based on Ecological Spatial Analysis). Jurnal Sains Informasi Geografis, 3(2), 100. https://doi.org/10.31314/jsig.v3i2.668

Sya, A., Zid, M., S, A. I., \& Putri, A. E. (2021). Pengelolaan Destinasi Pariwisata Berkelanjutan : Kasus Tanjung Lesung Provinsi Banten. 5(1), 27-32.

Wunani, D., Nursinar, S., \& Kasim, F. (2013). Kesesuaian Lahan dan Daya Dukung Kawasan Wisata Pantai 
Botutonuo, Kecamatan Kabila Bone, Kabupaten Bone Bolango. 1(September), 89-94. http://ejurnal.ung.ac.id/index.php/nike/article/view/1226 